\title{
Pengaruh Suplementasi Kolin Klorida terhadap Efisiensi Energi Bruto pada Sapi Perah Laktasi
}

\section{Effects of Choline Chloride Supplementation on Gross Energy Efficiency in Lactating Dairy Cattle}

\author{
R. G. Hayusasmita, D. W. Harjanti* dan Sutrisno \\ Fakultas Peternakan dan Pertanian Universitas Diponegoro, Semarang - 50275 \\ *E-mail: dianharjanti@undip.ac.id \\ (Diterima: 28 November 2017; Disetujui: 4 Februari 2018)
}

\begin{abstract}
ABSTRAK
Penelitian ini bertujuan untuk mengetahui pengaruh suplementasi kolin klorida dalam pakan terhadap efisiensi energi bruto sapi perah laktasi. Penelitian ini menggunakan 8 ekor sapi perah betina Friesian Holstein laktasi pada bulan laktasi ke-3 dan ke-4 dengan periode laktasi II. Pakan yang digunakan adalah rumput gajah dan konsentrat WA Feed, serta kolin klorida 60\% corncob dengan imbangan pemberian hijauan dan konsentrat $40: 60$. Rancangan yang digunakan adalah cross over designs dengan 2 perlakuan dan 4 ulangan. Perlakuan yang diujikan adalah $\mathrm{T}_{0}$ (ransum kontrol) dan $\mathrm{T}_{1}$ (ransum kontrol + kolin klorida $30 \mathrm{~g}$ /ekor/hari). Hasil penelitian menunjukan bahwa tidak ada perbedaan yang nyata antara konsumsi TDN pada kelompok $\mathrm{T}_{0}(9,05 \pm 1,44 \mathrm{~kg} / \mathrm{ekor} /$ hari $)$ dan $\mathrm{T}_{1}(9,61 \pm 1,40 \mathrm{~kg} / \mathrm{ekor} /$ hari $)$. Namun, produksi susu $4 \%$ FCM pada kelompok $\mathrm{T}_{1}(14,54 \pm 3,14 \mathrm{~kg} /$ ekor/hari $)$ lebih banyak $(\mathrm{P}<0,05)$ jika dibandingkan dengan kelompok $\mathrm{T}_{0}(13,36 \pm 2,63 \mathrm{~kg} /$ ekor/hari $)$. Efisiensi energi bruto menunjukan tidak berbeda antara $\mathrm{T}_{0}(0,28$ $\pm 0,05)$ dan $T_{1}(0,29 \pm 0,06)$. Simpulan hasil penelitian yang telah dilakukan bahwa suplementasi kolin klorida dalam pakan sebanyak 30 g/ekor/hari tidak mempengaruhi konsumsi TDN dan efisiensi energi bruto, namun dapat meningkatkan produksi susu 4\% FCM.
\end{abstract}

Kata kunci: efisiensi energi bruto, kolin klorida, produksi susu 4\% FCM, sapi perah

\section{ABSTRAK}

This study was carried out to determine the effect of choline chloride supplementation in lactating dairy cattle ration on gros energy efficiency. The animals used in this study were 8 lactating Friesian Holstein cows at the $3^{\text {rd }}$ and $4^{\text {th }}$ lactation in mounthin $2^{\text {nd }}$ lactation period. The composition of the ration consis of naiper grass and commercial concentrate (WA Feed) with ratio 40:60, choline chloride 60\% corncob. The experiment with 2 treatments and 4 replications in each treatment. The treatments were as follow $T_{0}$ (control ration) and $T_{1}$ (control ration + choline chloride $30 \mathrm{~g} /$ head/day). The result showed that choline chloride supplementation was no significant difference in TDN intake between group $T_{0}(9.05 \pm$ $1.44 \mathrm{~kg} / \mathrm{had} /$ day) and $T_{1}\left(9.61 \pm 1,40 \mathrm{~kg} / \mathrm{had} /\right.$ day). Milk production in $4 \%$ FCM of cows fed $T_{1}$ diet $(14.54$ $\pm 3.14 \mathrm{~kg} / \mathrm{head} /$ day) were higher than those of cows fed $T_{0}$ diet $(13.36 \pm 2.63 \mathrm{~kg} / \mathrm{head} /$ day). Gross energy efficiency did not differ between $T_{0}(0.28 \pm 0.05)$ and $T_{1}(0.29 \pm 0.06)$. It was concluded that choline chloride supplementation at $30 \mathrm{~g} / \mathrm{head} /$ day did not influence TDN intake and gross energy efficiency but increase $4 \%$ FCM milk production.

Keywords: choline chloride, dairy cows, gross energy efficiency, milk production 4\% FCM 


\section{PENDAHULUAN}

Kebutuhan pangan yang bergizi di Indonesia akan terus berkembang sejalan dengan pertambahan jumlah penduduk. Pertambahan penduduk berdampak pada peningkatan permintaan produk sumber protein asal ternak berupa susu, daging ataupun telur. Susu sapi merupakan pangan yang mudah diserap tubuh dan memiliki gizi yang tinggi. Konsumsi susu penduduk Indonesia terus meningkat dari tahun 2010 dengan $6,631 \mathrm{~kg} / \mathrm{kapita} /$ tahun sampai 7,090 $\mathrm{kg} / \mathrm{kapita} / \mathrm{tahun}$ pada tahun 2014 (BPS, 2014). Pengembangan usaha peternakan sapi perah dengan produksi susu yang optimal perlu dilakukan.

Hasil produksi susu yang sapi perah berasal dari metabolisme nutrien pakan yang dikonsumsi. Pakan yang dikonsumsi oleh sapi perah harus dapat memenuhi memenuhi kebutuhan hidup pokok, reproduksi dan produksi. Efisiensi penggunaan energi pakan saat produksi susu tinggi sangat diharapkan dapat optimal untuk menekan biaya pakan. Peningkatkan produksi susu dapat dilakukan dengan menambahkan kolin klorida sebagai aditif. Kolin merupakan bahan kimia organik dengan rumus molekul $\mathrm{C}_{5} \mathrm{H}_{14} \mathrm{NO}^{+}$, termasuk dalam golongan vitamin $\mathrm{B}$. Berperan penting dalam keutuhan struktur membran sel, metabolisme metil dan meningkatkan metabolisme lemak dalam hati (National Academies, 1998). Beberapa penelitian penggunaan kolin klorida berfokus pada sapi laktasi saat fase transisi. Fase transisi merupakan saat ternak membutuhkan energi yang besar untuk kebuntingan, hidup pokok, dan produksi susu. Penambahan kolin klorida pada sapi perah laktasi fase transisi $30 \mathrm{~g} /$ ekor/hari mampu meningkatkan produksi susu (Xu et al., 2006). Pinotti et al. (2005) menyatakan suplementasi kolin klorida 1220 g/ekor/hari pada fase transisi mampu meningkatkan produksi susu dan lemak susu. Puncak laktasi ternak saat 2 sampai 3 bulan post partum merupakan fase produksi susu tertinggi dan memerlukan energi tinggi untuk mendukung produksi. Zeizel dan da Costa (2009) menyatakan kolin dapat meningkatkan efisiensi pemanfaatan energi dari karbohidrat maupun dari katabolisme lemak dalam menghasilkan glukosa. Efisiensi energi yang tinggi berimplikasi pada peningkatan produksi susu. Pemberian kolin klorida terhadap efisiensi pemanfaatan energi pakan perlu dikaji pada sapi saat puncak laktasi, sehingga nilai efisiensi energi bruto dapat digunakan untuk potensi kolin klorida sebagai aditif pakan saat puncak laktasi.

Tujuan dari penelitian ini adalah untuk mengkaji pengaruh suplementasi kolin klorida dalam pakan terhadap efisiensi energi sapi perah laktasi. Manfaat dari penelitian ini adalah memberikan informasi pengaruh suplementasi kolin klorida dalam pakan terhadap efisiensi energi bruto sapi perah laktasi. Hipotesis penelitian ini adalah pemberian suplementasi kolin klorida dalam pakan dapat meningkatkan efisiensi energi bruto pada sapi laktasi.

\section{MATERI DAN METODE}

Penelitian dilaksanakan di Peternakan Sapi Perah Wahyu Agung, Desa Sumogawe, Kecamatan Getasan, Kabupaten Semarang, Jawa Tengah pada tanggal 28 Desember 2015 - 6 Maret 2016. Analisis susu dilaksanakan di Balai Veteriner, Kabupaten Boyolali, Jawa Tengah.

Materi yang digunakan dalam penelitian adalah 8 ekor sapi perah laktasi pada bulan laktasi ke-3 dan ke-4 dengan periode laktasi II. Bobot badan rata-rata sapi perah adalah $456 \pm 31 \mathrm{~kg}$ dan rata-rata produksi susu adalah $10,24 \pm 3,73 \mathrm{~kg}$. Pakan yang digunakan adalah rumput gajah dan konsentrat WA Feed dengan imbangan pemberian pakan 40:60. Rancangan penelitian yang digunakan yaitu Cross-over designs (Neter et al., 1990).

Kandungan nutrisi bahan pakan dan komposisi ransum yang disusun berdasarkan hasil analisis disajikan pada Tabel 1 dan Tabel 2. 
Tabel 1. Kandungan Nutrisi Bahan Pakan

\begin{tabular}{lccccc}
\hline Bahan pakan & BK $(\%)^{\mathrm{a}}$ & SK $_{(\%)^{\mathrm{a}}}$ & ${\text { LK }(\%)^{\mathrm{a}}}$ & ${\text { PK }(\%)^{\mathrm{b}}}$ & ${\text { TDN }(\%)^{\mathrm{d}}}$ \\
\hline Rumput gajah & 15,32 & 33,06 & 2,72 & 8,01 & $57,33^{\mathrm{c}}$ \\
Konsentrat WA feed & 88,39 & 19,92 & 4,55 & 16,70 & 74,74 \\
\hline
\end{tabular}

Keterangan :

$\mathrm{BK}=$ bahan kering, $\mathrm{SK}=$ serat kasar, $\mathrm{LK}=$ lemak kasar, $\mathrm{PK}=$ Protein kasar, $\mathrm{TDN}=$ total digestible nutrient. ${ }^{a}$ Laboratorium Nutrisi Pakan Fakultas Peternakan dan Perrtanian Universitas Diponegoro, 2015.

baboratorium Ekologi dan Produksi Tanaman Fakultas Peternakan dan Pertanian Universitas Diponegoro, 2015.

${ }^{\mathrm{c}}$ Berdasarkan rumus Hartadi et al. (1980).

${ }^{\mathrm{d} B e r d a s a r k a n}$ rumus Sutardi (2001).

Tabel 2. Komposisi Ransum Penelitian

\begin{tabular}{lcccccc}
\hline Bahan pakan & Rasio & BK (\%) & PK (\%) & SK (\%) & LK (\%) & TDN (\%) \\
\hline Rumput gajah & 40 & 6,13 & 3,20 & 13,22 & 1,08 & 22,93 \\
Konsentrat WA feed & 60 & 53,03 & 10,02 & 11,95 & 2,73 & 44,84 \\
Total & 100 & 59,16 & 13,22 & 24,17 & 3,81 & 67,77 \\
\hline
\end{tabular}

Penelitian dilakukan dalam empat tahap yaitu tahap persiapan, tahap adaptasi, tahap perlakuan dan pengambilan data dan analisis data. Tahap persiapan yaitu memilih sapi berdasarkan bulan dan periode laktasi setelah itu dilakukan pengukuran bobot badan dan produksi susu. Tahap adaptasi yaitu dilakukan selama 2 minggu, sapi yang digunakan diberi ransum perlakuan secara bertahap dengan tujuan agar sapi terbiasa mengkonsumsi ransum yang digunakan. Satu minggu pertama adaptasi dilakukan dengan tidak memberikan kolin klorida dan 1 minggu berikutnya adaptasi dilakukan dengan memberi kolin klorida. TTahap perlakuan dan pengambilan data dilakukan selama II periode untuk tiap periodenya dilakukan selama 3 minggu. Pada periode I, sapi dikelompokkan menjadi dua 2 dan setiap kelompok terdapat 4 ulangan yaitu, kelompok A adalah sapi yang diberi perlakuan $\mathrm{T}_{1}$ dan kelompok $\mathrm{B}$ adalah sapi yang diberi perlakuan $\mathrm{T}_{0}$. Perlakuan $\mathrm{T}_{0}$ adalah sapi yang tidak diberi kolin klorida sebagai kontrol dan perlakuan $T_{1}$ adalah sapi yang diberi suplementasi kolin klorida $30 \mathrm{~g} /$ ekor/hari. Pada periode ke II diberi perlakuan sebaliknya. Data yang diukur dalam peneilitian ini adalah :
1. Produksi susu yang kemudian dikorksi $4 \%$ FCM: rumus Wickes (1983), yaitu:

$$
4 \% \mathrm{FCM}=0,4 \mathrm{MY}+15 \mathrm{MFY}
$$

Keterangan:

FCM : Produksi susu terkoreksi lemak kadar 4\%

MY : Produksi susu

MFY : Produksi lemak

0,4 dan 15 : Konstanta Konsumsi TDN:

Konsumsi TDN (kg)

$=$ Konsumsi BK $(\mathrm{kg}) \mathrm{x} \% \mathrm{TDN}$

2. Efisiensi Energi Bruto, Pengukuran efisiensi energi bruto menggunakan rumus Brody (1974), yaitu:

Efisiensi Energi Bruto = $340 \times 2,20 \times \mathrm{FCM}(\mathrm{kg})$

$1814 \times 2,20 \times$ TDN (kg)

Keterangan :

FCM : Produksi susu terkoreksi lemak 4\%

TDN : Total nutrisi tercerna

340 : Nilai energi bruto $11 \mathrm{~b}$ FCM

1814 : energi bruto $1 \mathrm{lb}$ TDN 
Tabel 3. Pengaruh perlakuan terhadap konsumsi TDN

\begin{tabular}{lccccccccc}
\hline \multirow{2}{*}{ Perlakuan } & \multicolumn{8}{c}{ Ulangan (kg/ekor/hari) } & \multirow{2}{*}{ Rata-rata } \\
\cline { 2 - 9 } & 1 & 2 & 3 & 4 & 5 & 6 & 7 & 8 & \\
\hline $\mathrm{T}_{0}$ & 10,50 & 7,25 & 8,75 & 7,78 & 11,26 & 9,56 & 7,67 & 9,66 & $9,05 \pm 1,44$ \\
$\mathrm{~T}_{1}$ & 11,25 & 11,77 & 8,36 & 10,39 & 8,96 & 7,75 & 9,32 & 9,09 & $9,61 \pm 1,40$ \\
\hline
\end{tabular}

Tabel 4. Pengaruh perlakuan terhadap produksi susu 4\% FCM.

\begin{tabular}{lccccccccc}
\hline \multirow{2}{*}{ Perlakuan } & \multicolumn{8}{c}{ Ulangan (kg/ekor/hari) } & \multirow{2}{*}{ Rata-rata } \\
\cline { 2 - 9 } & 1 & 2 & 3 & 4 & 5 & 6 & 7 & 8 & \\
\hline $\mathrm{T}_{0}$ & 15,56 & 11,47 & 12,57 & 11,71 & 12,35 & 10,75 & 13,79 & 18,71 & $13,36 \pm 2,63^{\mathrm{b}}$ \\
$\mathrm{T}_{1}$ & 16,03 & 11,70 & 15,04 & 21,32 & 14,60 & 12,69 & 13,02 & 11,93 & $14,54 \pm 3,14^{\mathrm{a}}$ \\
\hline
\end{tabular}

Keterangan: Superskrip yang berbeda pada kolom yang berbeda menunjukan berbeda nyata $(\mathrm{P}<0,05)$.

HASIL DAN PEMBAHASAN

\section{Konsumsi Total Digestible Nutrien (TDN)}

Hasil perhitungan konsumsi TDN pada setiap perlakuan dapat dilihat pada Tabel 3. Konsumsi TDN penelitian besarnya berkisar 7,25 hingga 11,77 kg/ekor/hari.

Analisis ragam menunjukkan tidak berpengaruh nyata $(\mathrm{P}>0,05)$ penambahan kolin klorida terhadap konsumsi TDN ransum. Konsumsi TDN antar kelompok perlakuan dapat dikatakan sudah memenuhi untuk kebutuhan hidup pokok dan produksi susu. Tidak ditemukan perbedaan konsumsi TDN antar kelompok perlakuan dikarenakan suplementasi kolin klorida yang ditambahkan dalam pakan sebanyak $30 \mathrm{~g} / \mathrm{ekor} / \mathrm{hari}$ tidak meningkatkan palatabilitas ternak. Tinggi rendahnya konsumsi TDN itu dipengaruhi oleh jumlah konsumsi pakan. Hal ini dapat dikaitkan dengan hasil penelitian yang sama Trizana et al. (2016) tentang pengaruh penambahan kolin klorida dalam pakan terhadap produksi, total solid, dan persistensi susu sapi perah dimana hasil konsumsi BK menunjukan tidak berpengaruh nyata terhadap perlakuan dengan hasil konsumsi antar perlakuan $\mathrm{T}_{0}$ yaitu $13,29 \pm 2,08 \mathrm{~kg}$ dan $\mathrm{T}_{1}$ sebesar 14,12 $\pm 2,03 \mathrm{~kg}$. Hasil yang sama oleh Guretzky et al. (2006) dengan penambahan kolin klorida pada sapi perah laktasi sebanyak 30 g/ekor/hari tidak mempengaruhi konsumsi bahan kering.

\section{Produksi Susu 4\% FCM}

Hasil perhitungan produksi susu $4 \%$ FCM pada setiap perlakuan dapat dilihat pada Tabel 4. Hasil rataan produksi susu 4\% FCM besarnya berkisar 10,75 -21,32 kg/hari.

Hasil analisis ragam menunjukan bahwa produksi susu yang terkoreksi lemak $4 \%$ FCM berbeda nyata $(\mathrm{P}<0,05)$ antara perlakuan $\mathrm{T} 1$ dengan $\mathrm{T}_{0}$. Hasil penelitian yang sama juga dilaporkan oleh Xu et al. (2006) bahwa penambahan kolin klorida sebanyak 30 $\mathrm{g} /$ ekor/hari dapat meningkatkan produksi susu $4 \%$ FCM. Sapi yang diberi suplementasi kolin klorida sebanyak $30 \mathrm{~g} / \mathrm{ekor} / \mathrm{hari}$ menghasilkan produksi susu $4 \% \mathrm{FCM}$ sebanyak $34,0 \mathrm{~kg} / \mathrm{hari}$ sedangkan sapi yang tidak diberi suplementasi kolin klorida menghasilkan susu 27,7 kg/hari. Penambahan kolin klorida 30 g/ekor/hari dalam pakan menunjukan dapat meningkatkan produksi susu 4\% FCM. Kolin klorida berperan sebagai donor metil dimana metil digunakan untuk metabolisme terutama dalam katabolisme. Salah satu sumber katabolisme adalah glukosa, prosesnya disebut glikolisis. Dengan adanya kolin klorida jumlah metil akan bertambah banyak, sehingga katabolisme terjadi tidak hanya dari glukosa saja namun sumber katabolisme dapat diperoleh dari protein dan lipid. Proses ini secara tidak langsung dapat meningkatkan produksi 
Tabel 5. Pengaruh perlakuan terhadap efisiensi energi bruto.

\begin{tabular}{lccccccccc}
\hline \multirow{2}{*}{ Perlakuan } & \multicolumn{7}{c}{ Ulangan } & \multirow{2}{*}{ Rata-rata } \\
\cline { 2 - 8 } & 1 & 2 & 3 & 4 & 5 & 6 & 7 & 8 & \\
\hline $\mathrm{T}_{0}$ & 0,28 & 0,30 & 0,27 & 0,28 & 0,21 & 0,21 & 0,34 & 0,36 & $0,28 \pm 0,05$ \\
$\mathrm{~T}_{1}$ & 0,27 & 0,19 & 0,34 & 0,38 & 0,31 & 0,31 & 0,26 & 0,25 & $0,29 \pm 0,06$ \\
\hline
\end{tabular}

susu. Hal ini sesuai dengan pendapat Pinotti et al. (2002) bahwa kolin klorida bertindak sebagai donor metil dan memungkinkan lebih banyak Met yang tersedia untuk menstimulasi pembentukan susu dan lemak susu, dengan cara meningkatkan sintesis lipoprotein, glukoneogenesis, dan menyediakan metil untuk sintesis fosfolipid dalam hati.

Kolin klorida berperan untuk meningkatkan metabolisme dalam hati. Kolin klorida mencegah terjadinya penumpukan lemak dalam hati dengan melalui ekspor lippid. Kolin klorida dimanfaatkan secara optimal untuk mengubah lemak dalam hati menjadi lipoprotein, dimana lipoprotein merupakan prekusor utama dalam sintesis lemak susu didalam sel epitel, sehinggal lemak susu meningkat. Hal ini sesuai dengan pendapat Mohsen et al. (2011) bahwa pemberian kolin klorida dapat meningkatkan produksi $4 \%$ FCM karena salah satu atau lebih dari alasan berikut yaitu dengan meningkatkan ekspor lemak dari metabolisme hati dan kolin klorida berkontribusi terhadap pencegahan gangguan metabolisme serta kerugian ekonomi terkait dengan metabolism lipid yang tidak normal.

\section{Efisiensi Energi Bruto}

Hasil suplementasi kolin klorida dalam pakan terhadap efisiensi energi bruto pada sapi perah laktasi dapat dilihat pada Tabel 5. Diperoleh hasil efisiensi energi bruto yang nilainya berkisar antara $0,21-0,38$.

Berdasarkan hasil analisis ragam menunjukan bahwa tidak ada perbedaan yang nyata $(\mathrm{P}>0,05)$ penambahan kolin klorida terhadap efisiensi energi bruto. Rata-rata nilai efisiensi energi bruto $T_{0}$ dan $T_{1}$ masing-

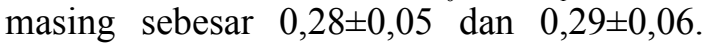
Hal ini menunjukan bahwa penambahan kolin klorida tidak mempengaruhi efisiensi energi bruto. Sapi yang digunakan dalam penelitian termasuk memiliki efisiensi energi bruto yang bagus. Menurut Brody (1974) sapi yang memiliki energi bruto 0,25-0,34 termasuk good producer. Tinggi rendahnya nilai efisiensi energi bruto dipengaruhi oleh beberapa faktor seperti konsumsi TDN dan produksi susu terkoreksi 4\% FCM.

Hasil penelitian ini menunjukan bahwa konsumsi TDN tidak berbeda nyata sehingga sebanding dengan hasil efisiensi energi bruto yang tidak berbeda nyata juga. Hal ini disebabkan karena kolin klorida tidak mempengaruhi palatabilitas pakan ternak, sehingga tidak menyebabkan konsumsi BK ransum terpengaruhi atau meningkat. Tidak adanya interaksi pada konsumsi BK ini menyebabkan tidak ada interaksi pada konsumsi TDN. Sidqi et al. (2012) menyatakan bahwa efisiensi produksi susu dari setiap sapi dapat dibandingkan dengan memperhitungkan susu yang diproduksi dengan energi dalam jumlah TDN bahan ransum yang dikonsumsi. Penambahan kolin klorida sebanyak $30 \mathrm{~g} /$ ekor/hari mampu meningatkan produksi susu $4 \%$ FCM, sehingga nilai efisiensi energi bruto lebih tinggi kelompok yang diberi kolin klorida dari pada kelompok yang tidak diberi kolin klorida.

Bila ditinjau dari imbangan pakan dapat dibandingkan dengan penelitian Musnandar (2011) tentang efisiensi energi pada sapi perah holstein yang diberi berbagai imbangan rumput dan konsntrat yang hasilnya menunjukan bahwa efisiensi energi bruto terbesar pada imbangan rumput gajah dan konsentrat $50: 50 \%$ yaitu $0,28 \pm 0,02$ dan terendah pada imbangan $40: 60 \%$ yaitu $0,25 \pm 0,03$. Hal ini bertolak belakang dengan penelitian yang menambahkan kolin klorida sebayak $30 \mathrm{~g} / \mathrm{ekor} / \mathrm{hari}$ dalam imbangan 
40:60 \%. Pada penelitian tersebut didapatkan hasil rataan efisiensi energi bruto yang lebih tinggi dibandingkan dengan penelitian Musnanadar (2011) yang menyebutkan bahwa pada imbangan 50 : 50 merupakan hasil yang tertinggi. Melihat hasil ini maka dapat disimpulkan bahwa penambahan kolin klorida sebanyak $30 \mathrm{~g} / \mathrm{ekor} / \mathrm{hari}$ dapat meningkatkan efisiensi energi bruto, meski belum secara signifikan. Meningkatnya nilai efisiensi energi bruto dapat dimanfaatkan oleh peternak untuk mengembangkan usahanya guna peningkatan efisiensi ekonomis sehingga mendapat keuntungan yang maksimal. Hal ini sesuai dengan pendapat Mohsen et al. (2011) bahwa penambahan kolin klorida mampu meningkatkan pendapatan rata-rata dari produksi susu. Hal ini dapat dikaitkan dengan konsumsi TDN yang tidak berbeda nyata.

\section{KESIMPULAN}

Berdasarkan hasil penelitian yang telah dilakukan dapat disimpulkan bahwa penambaha kolin klorida dalam pakan sebanyak $30 \mathrm{~g} /$ ekor/hari tidak mempengaruhi konsumsi TDN ransum, dan efisiensi energi bruto, namun dapat meingkatkan produksi susu terkoreksi lemak 4\%.

\section{DAFTAR PUSTAKA}

Brody, S. 1974. Bioenergetics and Growth. Hafner Press. Collier Mc Millan Canada Ltd

Guretzky, N., A. Janovick, D. B. Carlson, J. E. Garrett and J. K. Drackley. 2006. Lipid metabolite profile and milk production for Holstein and Jersey cows fed rumen-protected choline during the periparturient period. J. Dairy Sci. 89 (1): $188-200$.

Hartadi, H., L.C. Kearl, S. Reksohadiprojo, L.E. Harris dan S. Lebdosukoyo. 1980. Tabel-tabel dari komposisi bahan makanan. Data ilmu makanan ternak untuk Indonesia. Gadjahmada

\section{University Press. Yogyakarta}

Mohsen, M.K., M.H.A. Gaafar, M.M. Khalafalla, A.A. Shitta and A.M. Yousif. 2011. Effect of rumen protected choline supplementation on digestibility, rumen activity and milk yield in lactating Friesian cows. Slovak. J. Anim. Sci. 44 (1): 13 - 20.

Musnandar, E. 2011. Efisiensi energi pada sapi perah Holstein yang diberi berbagai imbangan rumput dan konsentrat. Jurnal Peternakan dan Pertanian. 13 (2): $53-58$.

National Academies. 1998. Dietary Reference Intakes for Thiamin, Riboflavin, Niacin, Vitamin B6, Folate, Vitamin B12, Pantothenic Acid, Biotin and Choline. National Academy Press, Washington, D.C.

Neter, J. A., W. Wasserman, and M. H. Kutner. 1990. Applied linear statistical models. Third edition. Irwin, Homewood, Illinois.

Pinotti, L., A. Baldi and V. Dell'Orto. 2002. Comparative mammalian choline metabolism with emphasis on highyielding dairy cow. Nutr. Res. Rev. 15(2): $315-331$.

Pinotti, L., A. Campagnoli, V. Dell'Orto and A. Baldi. 2005. Choline: Is there a need in the lactating dairy cow?. Livestock Prod. Sci. 98 : 149 -152

Sidqi, R., M. Makin dan Dwi Suharwanto. 2014. Pengaruh pemberian konsentrat basah dan kering terhadap efisiensi produksi susu dan efisiensi ransum terhadap sapi perah peranakan friesian holstein. Jurnal Ilmu Ternak. 3(4):1-10.

Sutardi, T. 2001. "Revitalisasi P eternakan $S$ api $P$ erah melalui $P$ enggunan $R$ ansum $\mathrm{B}$ erbasis L imbah P erkebunan dan $\mathrm{S}$ uplemen $\mathrm{M}$ ineral $\mathrm{O}$ rganik." Laporan Akhir RUT VIII.1 Institut P ertanian Bogor. Bogor

Trizana, D., Santoso, S.A.B., dan Soejono, C.B. 2016. Pengaruh penambahan 
kolin klorida dalam pakan terhadap produksi, total solid, dan persistensi susu sapi perah laktasi. Jurnal Ilmuilmu Peternakan. 26 (1): $66-74$.

Wickes, R.B. 1983. Feeding experimentwith dairy catlle. In. Dairy Catlle Reaserch Techniques. Edited by TermouthQueensland of Primary Industries, Australia.
Xu, G., J. An Ye, L. Jianxin and Y. Yu. 2006. Effect of rumen-protected choline addition on milk performance and blood metabolic parameters in transition dairy cows. J. Anim. Sci. 19 (1): 390-395.

Zeizel, S. H. and K. A. Da Costa. 2009. Choline: An essensial nutrient for public health. Nutrition Review. 67(11): 615-623. 